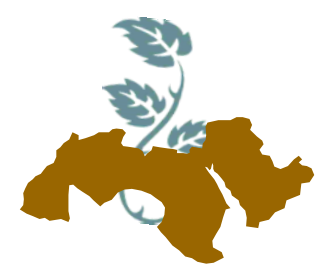

Arab Univ. J. Agric. Sci., Ain Shams Univ., Cairo, 25(2), 243-257, 2017

\title{
IN VITRO MICROTUBERIZATION OF POTATO: EFFECT OF EXPLANT DENSITY, SOURCE, AND GENOTYPE
}

\author{
Mohamed, F.H.; K.E. Abdel-Hamid; Genesia F. Omar and Basma A. El-Safty \\ Hort., Dept., Faculty of Agriculture, Suez Canal University, Ismailia, Egypt
}

Keywords: Solanum tuberosum L., microtuber, microshoots, Planting density, Explant, Genotypes.

\begin{abstract}
This study was conducted to examine explant density and source on production of in vitro potato microtubers, as well as survey of different newlyintroduced potato cultivars for their microtuberization capacity at the Plant Tissue Culture Facility of the Department of Horticulture, Suez Canal University between 2014 until 2016. Results indicated that as culture density from single node explants increased, microtuber number and yield/petri dish were also increased. However, at the lowest density (10 explants/petri dish), the \% tuberization and the average microtuber weight increased significantly over the higher densities $(20,25$ and 30 explants/petri dish). Potato microtuber production from plantlets grown in vitroon microtuberization induction medium (liquid over solid media) was also studied using 5, 10 and 15 plantlets per jar.Results showed that microtuber number and yield/jar increased gradually with increasing plantlet density. However, on per plantlet basis, microtuber number increased at the lowest density. Microtuber yield/jar increased significantly at the highest density (1099 mg/jar) compared to 563.6 $\mathrm{mg} / \mathrm{jar}$ at the lowest density. Average microtuber weight was also affected by culture density and genotype. At the lowest density, microtubers were significantly heavier than at the high density, and the cv. 'Safrane' recorded the highest weight per microtuber. Regarding the effect of explant source on microtuber production, results indicated that the use of single node explants derived from the top of the plantlet produced more microtubers than those taken from the basal part, or 3 node segments. Explant source also affected microtuber yield/dish. Single nodes from the top produced the highest
\end{abstract}

(Received 12 April, 2017)

(Revised 17 May, 2017)

(Accepted 4 June, 2017) yield compared to 3-nodes segment from the top (205 vs. $104.8 \mathrm{mg}$ ). The highest mean microtuber fresh weight was obtained from the culture of 3 node layered segment from the plantlet base, while single nodes from the top recorded lower microtuber fresh weight. The highest microtuber fresh weight was recorded in cv 'Universa' (114.3 mg) using single nodes from the plantlet base. Differences among the tested potato cultivars in microtuber production were detected.

\section{INTRODUCTION}

In Egypt, it is estimated that about 72.918 tons of tuber seeds were imported from Europe in the year 2012 (FAOSTAT, 2012), for summer plantation, with a value of about $\$ 6.8$ million. Potato is vegetatively propagated by seed tubers, either by using whole small tubers or dividing large size tubers into 2-4 pieces. Because potato is susceptible to many viral, bacterial, and fungal diseases, a conservative seed certification program should be implemented in seed tuber production fields, and in places where seed tubers are prepared for planting.

Because of the high cost of importing healthy seed tubers, and the increasing demand for growing and expanding the potato crop, potato seed tuber production in Egypt should be of higher priority. Tissue-culture techniques are utilized for the production of disease-free nuclear stock materials (microshoots or microtubers) with subsequent production of minitubers from the nuclear stock, under greenhouse conditions. To optimize massproduction of microtuber, factors affecting their production need to be further studied, especially in the new potato cultivars currently under cultivation in Egypt.

Microtubers are easy to be stored and transported and do not require ex vitro acclimatization. Therefore, the establishment of optimal conditions 
for their in vitro formation could be of a considerable value. Much of the published reports on in vitro potato microtuberization have been focused on medium composition, viz, high sucrose level (Garner and Balke, 1989) and plant growth regulators type and concentration (Aryakia and Hamidoghli, 2010). However, little attention has been paid to the effect of explant source, age, or inoculum density in the culture jars and their interaction with the different genotypes.

Nikopoulos (1993) examined two planting densities of single node cutting viz, 0.6 and 1.8 average explants per one $\mathrm{ml}$ of semi-solid medium containing $6 \%$ sucrose and found no significant differences between the two explant densities, regarding microtuber yield/jar and \% abnormal microtubers, although mean fresh weight of a microtuber decreased gradually as the planting density increased.Instead of testing the density of single node explants, Tabori et al (2000) studied whole plantlet density per jar on aerial microtuberization potential in four potato cultivars and the results indicated that the time of tuber development was earlier with increasing plantlet density, for all cultivars, while number of microtubers/jar was not affected. High planting density (30-40 plantlets per jar) increased the number of well-sized microtubers ( $>4 \mathrm{~mm}$ ) and microtuber yield (Tabori et al 2000).

For the development of potato microtubers, plantlets containing about 6-10 nodes are divided into nodal segments and usually cultured randomly on the surface of the microtuberization medium, irrespective of their position on the plantlets. However, the induction of microtuber may vary according to the position in the plantlet from which it was isolated. In this respect, Ahmadian and Zarghami (1998) reported that the upper nodes derived from in vitro plantlets produced microtubers with more length, diameter, and weight. However, results of Nikopoulos (1993) revealed that the position of the node on the mother plantlet did not affect microtuber yield, but slightly affected microtuber size and quality as number of misshapen tubers.

Levy et al (1995) studied the difference between culturing whole plantlet and single nodes on MS medium containing $8 \%$ sucrose and $5.0 \mathrm{mg}$ ancymidol. They found that microtuber diameter was higher $(11 \mathrm{~mm})$ using whole plantlet as compared to single nodes which produced microtubers with diameter up to $6 \mathrm{~mm}$ (Levy et al 1995). In line with these, results of Leclerc et al (1994) showed that layered plantlet produced higher number and rapid induction of microtubers compared with nodal cutting explants.
In vitro microtuber induction was examined by Struik (1999) as affected by explant position using stem cuttings from in vitro plantlets with different number and position of leaves. It was found that buds (nodes) that are most distant from the illuminated leaves showed the highest microtuber induction and the basic pattern of tuberization was basipetal (Struik, 1999).

It was also reported by Myeong et al (1990) that the culture of potato nodes taken from the middle or basal part of the plantlet produced more number of microtubers than those taken from the upper part. In agreement with these results, Escalante and Langille (1998) found that node position on the plantlet affected microtuber growth. Explant from the basal part significantly produced more number and larger microtubers than did apical explants (Escalante and Langille, 1998). In addition, sub apical buds produced more and larger microtuber than apical ones, and the different between basal and medial nodal explants was not significant with respect to microtuber number or size (Escalante and Langille, 1998).

The study of Fatima et al (2005) demonstrated that in vitro tuberization in terms of number and yield of microtubers were significantly higher when plantlet or13 single nodes cultured than the culture of shoot tip explants. In according with these results, Kanwal et al (2006) reported that nodal explants produced more microtubers (4-5/explant) in 29-30 days planting with higher fresh weight on MS basal medium $+8 \%$ sucrose, than the culture of shoot apex explant which produced an average of 4 microtubers/explants in 34 days (Kanwal et al (2006). The average fresh weight of microtuber was also lower using shoot apex explants. Sharma et al (2011) found that double node explant was better over single node explant for growth vigor of plantlet in some potato cultivars.

The objective of the present study wasto maximize the production of potato microtubers in vitro through the examination of several factors influencing their formation, such as inoculum density, explant source and types. In addition, different newly-introduced potato cultivars were surveyed for their response to the different in vitro treatments, as well as their microtuberization capacity.

\section{MATERIAL AND METHODS}

A laboratory experiments were conducted to optimize the in vitro microtuber induction and development of potato (Solanum tuberosum L.) through studyingthe effects of explant (single 
nodes or whole plantlets inoculum density per culture container, explant type as taken from the top or basal part of the plantlets as well as the genotype effect.

\section{Plant materials}

Several potato cultivars were utilized as will be outlined per each experiment. The cultivars are part of the in vitro germplasm preservation and multiplication program held at the Plant Tissue Culture Facility of the Department of Horticulture, Suez Canal University starting in 2010 until recently. Some cultivars were obtained from the Horticulture Research Center, Vegetable Research Branch, Dokki, Giza, Egypt including 'Provento', 'Sante', 'Spunta', 'Diamant', 'Arinda', 'Agria', 'Nicola' and 'Bolista'. The rest of cultivars were obtained from the French seed potato project held at the Experimental Farm of the Faculty of Agriculture, Suez Canal University in 2007. These include the new cultivars: 'Safrane', 'Universa', and 'Triomph'.

\section{Micropropagation procedures}

Certified seed tubers from the previously mentioned potato genotypes were allowed to grow in the greenhouse in $15 \mathrm{~cm}$ plastic pots filled with vermiculite, one tuber per pot until sprouting took place. Sprouts $(5 \mathrm{~cm})$ were collected, rinsed with tap water for $10 \mathrm{~min}$. In a laminar air- flow hood, sprout tips were sterilized with $10 \%$ Clorox solution containing $5.25 \%$ sodium hypochlorite for $3 \mathrm{~min}$., then washed three times in sterile distilled $\mathrm{H}_{2} \mathrm{O}$. Shoot meristem tips $(0.5 \mathrm{~mm})$ were isolated under binuclear at 20x magnification and cultured in $15 \mathrm{~cm}$ test tube (one meristem/test tube) containing $10 \mathrm{ml}$ of MS medium (Murashige and Skoog, 1962). Whole plantlet containing about 10 nodes were derived from the culture of each meristem tip. Per each cultivar, meristem-derived plantlets were utilized for further in vitro multiplication using single node cuttings.

\section{General laboratory procedures}

In all in vitro experiments, otherwise mentioned, MS medium basal salts and vitamins (4.2g/l) without PGR was utilized during multiplication stage. Per each liter of MS medium, $30 \mathrm{~g} \mathrm{su-}$ crose was added and the $\mathrm{pH}$ was adjusted to 5.7 before the addition of $7.0 \mathrm{~g} / \mathrm{l}$ agar for solid medium.

For in vitro microtuberization media, MS salts and vitamins was supplemented with $80 \mathrm{~g} / \mathrm{l}$ su- crose for direct microtuber development from nodal segment explants. In experiments where microtuber production from plantlets was examined, liquid MS medium (20 ml/jar) supplemented with $80 \mathrm{~g}$ sucrose was poured onto jars containing plantlets grown in solid medium as a base. Media in glass culture containers (test tubes or glass jam jars) were autoclaved for $30 \mathrm{~min}$. under $121^{\circ} \mathrm{C}$ at $15 \mathrm{psi}$, then cold stored until used. In experiment utilizing disposable sterile petri dishes $(8 \mathrm{~cm}$ diameter), autoclaved media were added directly (30 ml/dish) in a laminar air-flow hood, then sealed with parafilm strips until use.

\section{Experiment 1: Effect of explant density on mi- crotuber production from single nodes}

Five potato cultivars (cvs.): 'Safrane', 'Sante', 'Agria', 'Bolista'and 'Provento' were tested for their microtuberization from single node explants. The culture density treatments were 10, 15, 20, 25 and 30 explants per container. Explants were cultured on MS medium amended with $80 \mathrm{~g}$ sucrose and solidified with $7.0 \mathrm{~g} / \mathrm{l}$ agar. The culture containers were sterile plastic petri dishes filled with $30 \mathrm{ml}$ medium each. After the culture of single node explants, petri dishes were covered and sealed with Parafilm strips. Petri dishes were then arranged on the shelf in a growth room in $5 \times 5$ factorial Complete Randomized Design (CRD) with 5 replications. Cultures were incubated at $20^{\circ} \mathrm{C}$ under darkness. Microtubers were harvested after 8 weeks and data were recorded on microtuber number, microtuber yield (mg) per dish. Average microtuber weight was calculated by divining microtuber yield by number. As most single node explants have formed roots and sprouting by the end of the experiment, data were also taken on $\%$ of rooted and sprouted explant for every $\mathrm{cv}$. $\mathrm{x}$ density treatment. These percentages were calculated as follows:\% early microtuber induction $=($ No. of explants with initial microtuber/total No. of explants/dish) $\times 100 ; \%$ sprouted explant $=($ No. of sprouted explants/No. of explant per dish) x 100; $\%$ rooted explants $=($ No. of rooted explants/total No. of explant per dish) $\times 100$.

\section{Experiment 2: Effect of planting density on mi- crotuber productionfrom in vitro plantlets}

In this experiment, six potato cultivars; 'Safrane', 'Diamant', 'Agria', 'Provento', 'Nicola', and 'Universa' were tested for their microtuberization potential from complete plantlets in different 
densities, viz; 5, 10 and 15 plantlets per glass jar (ca $300 \mathrm{ml}$ ) containing $25 \mathrm{ml}$ solid microtuberization medium per jar (MS+ $80 \mathrm{~g}$ sucrose $+7.0 \mathrm{~g} / \mathrm{l}$ agar) for two weeks, followed by adding $20 \mathrm{ml}$ liquid MS medium (MS+ $80 \mathrm{~g}$ sucrose) per jar in a laminar air-flow hood. The cultured explants were taken from jars in multiplication stage derived from single node explants, each plantlet contained an average of 8 nodes. Cultured jars were then arranged on the shelves of the growth room under $20^{\circ} \mathrm{C}$ in the dark in $6 \times 3$ factorial experiment in CRD design ( 6 cvs. $\times 3$ densities) with 5 replicates. After 6 weeks from adding the liquid medium, microtubers were harvested and data were taken on their number and yield per jar and per plantlet, as well as average microtuber weight as mentioned in the previous experiment.

\section{Experiment 3: Effect of explant source on pota- to microtuberization in petri dish}

The culture of single node explant on microtuber induction medium normally results in the formation of microtubers different in frequency and size. This experiment was conducted to test whether or not these differences are due to the position on the whole plantlets (source) from which nodal segment explants were taken. Five potato cvs., namely: 'Diamant', 'Nicola', 'Agria', 'Universa' and 'Spunta' were used. Explant types examined were:single node explant isolated from the first three nodes on the top of the plantlet $(\mathrm{S} / \mathrm{T})$; single node isolated from the base of the plantlet $(S / B)$; layered segment from top part with 3 nodes $(\mathrm{L} / \mathrm{T})$; layered segment from basal part with 3 nodes (L/B).

Explant source treatments from each cultivar were cultured in $8 \mathrm{~cm}$ plastic sterile petri dishes, each contains sterilized $30 \mathrm{ml}$ of solid MS medium supplemented with $80 \mathrm{~g} / \mathrm{l}$ sucrose $+7.0 \mathrm{~g} / \mathrm{l}$ agar. Six single nodes from the plantlet top (S/T) or base $(\mathrm{S} / \mathrm{B})$ were horizontally cultured per dish, while two nodal segments of 3-nodes each isolated from the top $(\mathrm{L} / \mathrm{T})$ or basal $(\mathrm{L} / \mathrm{B})$ plantlet part were horizontally layered on the surface of microtuberization medium (MS basal salts and vitamins $+80 \mathrm{~g} \mathrm{su}$ crose solidified with $7.0 \mathrm{~g} / \mathrm{l}$ agar). After 8 weeks, microtubers were harvested and data were taken on number of microtubers per dish, microtuber yield (mg) per dish and average microtuber weight (mg).

\section{Experiment 4: Effect of explant source on pota- to microtuberization in glass jars}

This experiment was a repeating of experiment 3 using the same explant sources, plus whole 6nodes segment and the response was tested on the two potato cultivars:'Nicola' and 'Arinda', grown in glass jars.

\section{Experiment 5: Effect of potato genotypes on microtuberization}

Ten potato genotypes were tested for their microtuberization potential. The tested cvs were 'Safrane', 'Diamant', 'Spunta', 'Triomph', 'Nicola', 'Universa', 'Agria', 'Provento', 'Arinda'and 'Bolista'. Single node explants (5 explants/jar) from each cv. were cultured on glass jars, each amended with 30 $\mathrm{ml}$ MS medium salts and vitamins (without PGR) plus $30 \mathrm{~g} / \mathrm{l}$ sucrose and solidified with $7.0 \mathrm{~g} / \mathrm{l}$ agar. Incubation took place at $24 \pm 1^{\circ} \mathrm{C}$ under light from while fluorescent lamps providing light of $2 \mathrm{k}$ lux. After 40 days, plantlets were formed from each single node explant. At this stage, cultured jars were moved to the laminar air flow hood where 20 $\mathrm{ml}$ liquid microtuber formation medium was added to each jar, they were then incubated at $20^{\circ} \mathrm{C}$ under darkness. Jars were arranged on the shelves of a growth chamber in a CRD design with 10 replicates (jars) per genotype. After 8 weeks, microtubers were harvested and data were taken on number and yield $(\mathrm{g})$ of microtubers per jar, and average microtuber weight (mg).

\section{Statistical analysis}

All in vitro experiments were conducted twice with at least five replications. Data were combined and subjected to ANOVA using Costat computer program (CoStat Statistical Software; CoHort Software, Berkeley, California)and the differences between means were separated using Duncan's multiple-range testat $5 \%$ significance level.

\section{RESULTS}

The current study included different in vitro experiments towards the optimization of potato microtuber production.

Experiment 1: Effect of explant density on microtuber production from single nodes

In this experiment, single nodes of different densities per petri dish $(10,15,20,25$ and 30 nod- 
al segments/dish) were examined for their direct microtuber induction and development from leaf axil on MS medium supplemented with $80 \mathrm{~g} / \mathrm{l} \mathrm{su}$ crose in the dark. Five potato cultivars were tested for their microtuberization potentials under the different explant densities, namely 'Sante', 'Safrane', 'Agria', 'Bolista' and 'Provento'.

Results of the main effects of explant density and cultivars as well as their interaction on number of microtuber/dish and percentage of tuberized explants are shown in Table (1A). Results indicated that number of microtubers was significantly affected by the inoculum density and the largest number of microtubers was obtained from the culture of 30 explants per dish (21.2), while the lowest number of microtubers (ave. 8.24) was found using 10 explants /dish. It was clear from the results of main effect of explant density that microtuber number increasedwith each increase in explant density.However, the \% tuberized explants were higher at the lowest explant density $(82.4 \%)$, then decreased with each increase in density (Table 1A).

Results also demonstrated significant differences among the examined potato cultivars for number of microtubers as tested over all the examined explant densities (Table 1A). In this respect, the potato $\mathrm{cv}$. 'Provento' produced the largest number of microtubers (ave. 18.16), followed by cv. 'Bolista' (ave. 16.96) and 'Sante' (14.3). The cvs.'Provento' and 'Bolista' had also the largest \% of tuberization (92.7\%), followed by 'Sante' (72.5\%) while only about $50 \%$ of the explants in the two cvs. 'Safran' and 'Agria'produced microtubers.

The interaction of density $x$ cultivars was significant for the number of microtuber produced/dish. In this regard, the highest microtuber number (23.6) was recorded in cv. 'Provento' at 30 explants/dish while the lowest number (2.3 microtuber/dish) was found in cv. 'Safrane' at the lowest explant density. In all cultivars, except cv. 'Sante', the number of microtubers increased with the increase in explant inoculum density per dish. It was also estimated that the largest percentages of the tuberized explants were in cvs. 'Bolista' and 'Provento' (140\% and $130 \%$, respectively) at the lowest explant density treatment, while only $23 \%$ of the explants in cv. 'Safrane' produced microtuber at the same density.

Results of the main effect of explant density and cultivars as well as their interaction on microtuber yield (mg/dish) are presented in Table (1B). Results of ANOVA indicated significant differences among the tested explant densities on potato mi- crotuber yield and the largest yield (338.1 mg/dish) was recorded at the highest density (30 explants/dish) followed by those at 25 explant/dish with $(274 \mathrm{mg})$. The lowest microtuber yield was found at 15 and 20 explant/dish treatment. The differences among potato cultivars in microtuber yield followed the same trend as in number of $\mathrm{mi}$ crotuber. In this respect, the highest microtuber yield was recorded in cv. 'Provento' (530.8 $\mathrm{mg} / \mathrm{dish}$ ), followed by cv. 'Bolista' (266 mg/dish), while the lowest yield was recorded in cv. 'Agria' (ave. $102.4 \mathrm{mg} / \mathrm{dish}$ ).

The interaction of explant density $x$ cultivar was significant for microtuber yield. The highest recorded microtuber yield (632 mg/dish) was found in cv. 'Provento' at the lowest explant density, while at the same density, the cv. 'Safrane' recorded the lowest yield.

With regard to the average microtuber weight, results indicated significant difference among the tested explant densities and cultivars, as well as their interaction (Table 1C). The highest average microtuber weight was recorded at the lowest explant densities (10 and 15 explants per dish), and declined with each increase in explant density up to 30 explants/dish.

Significant difference among potato cultivars in average microtuber weight was also detected. The cv. 'Provento' had the heaviest microtuber (28.32 $\mathrm{mg}$ ), followed by the cvs.'Sante' and 'Safrane', while microtuber of the cv. 'Agria' was the lowest in weight $(11.63 \mathrm{mg})$.

The interaction effect of explant density $x$ cultivar was significant in most cultivars, a reduction in average microtuber weight was observed with the increase in explant density. The highest microtuber weight was recorded in cv. 'Provento' (ave. 43.4 $\mathrm{mg})$ at 15 explants/dish, while the lowest microtuber weight was found in cv. 'Agria' $(7.3 \mathrm{mg}$ ) at the highest explant density.

After two month in culture, it was observed that the cultured single node explants formed vegetative, etiolated sprouts and roots, (Fig. 1) with or without the formation of microtuber from the leaf axil of nodal segment. The percentage of explants forming sprouts are presented in Table (2-A) under the influence of explant density and cultivars. Results demonstrated significant differences among explant densities on \% sprouted explants. It was found that with the increase in explant density per dish, the \% sprouting increased from $53.3 \%$ at 10 explants/dish to $81.9 \%$ at 30 explants/dish.

Regarding the main effect of cultivars, data indicated that both cvs. 'Safrane' and 'Agria' had the 
Table 1. Effect of single node explant density on microtuber production in petri dish in 5 potato cultivars. A. No. microtuber/dish and \% of tuberization*

\begin{tabular}{|c|c|c|c|c|c|c|}
\hline Density & Sante & Safrane & Agria & Bolista & Provento & $\begin{array}{c}\text { Mean } \\
\text { Density }\end{array}$ \\
\hline 10 & $\begin{array}{l}6.3 h^{\star \star} \\
(63)^{\star}\end{array}$ & $\begin{array}{l}2.3 \mathrm{j} \\
(23)\end{array}$ & $\begin{array}{l}5.6 \mathrm{~h} \\
(56)\end{array}$ & $\begin{array}{l}14.0 \mathrm{f} \\
(140)\end{array}$ & $\begin{array}{c}13.0 \mathrm{~g} \\
(130.0)\end{array}$ & $8.24 E$ \\
\hline 15 & $\begin{array}{c}13.5 \mathrm{~g} \\
(90)\end{array}$ & $\begin{array}{l}5.0 \mathrm{hi} \\
(33.3)\end{array}$ & $\begin{array}{l}5.6 \mathrm{~h} \\
(37.3)\end{array}$ & $\begin{array}{l}14.6 \mathrm{f} \\
(97.3)\end{array}$ & $\begin{array}{c}15.0 \mathrm{e} \\
(100.0)\end{array}$ & 10.70D \\
\hline 20 & $\begin{array}{l}16.3 d \\
(81.5)\end{array}$ & $\begin{array}{c}11.0 \mathrm{~h} \\
(55)\end{array}$ & $\begin{array}{l}6.0 \mathrm{~h} \\
(30)\end{array}$ & $\begin{array}{c}15.6 \mathrm{de} \\
(78.0)\end{array}$ & $\begin{array}{c}19.6 \mathrm{bc} \\
(98.0)\end{array}$ & $13.70 \mathrm{C}$ \\
\hline 25 & $\begin{array}{c}14.0 \mathrm{~g} \\
(56)\end{array}$ & $\begin{array}{c}15.3 \text { de } \\
(61.2)\end{array}$ & $\begin{array}{c}14.0 \mathrm{f} \\
(56)\end{array}$ & $\begin{array}{c}19.6 \mathrm{bc} \\
(78.4)\end{array}$ & $\begin{array}{c}19.6 \mathrm{bc} \\
(78.4)\end{array}$ & $16.40 \mathrm{~B}$ \\
\hline 30 & $\begin{array}{c}21.6 \mathrm{~b} \\
(72)\end{array}$ & $\begin{array}{c}18.6 \mathrm{c} \\
(62)\end{array}$ & $\begin{array}{c}21.3 \mathrm{~b} \\
(71)\end{array}$ & $\begin{array}{c}21.0 \mathrm{~b} \\
(70)\end{array}$ & $\begin{array}{l}23.6 \mathrm{a} \\
(78.6)\end{array}$ & $21.20 \mathrm{~A}$ \\
\hline Mean CV. & $\begin{array}{c}14.30 \mathrm{C} \\
(72.5)\end{array}$ & $\begin{array}{c}10.44 \mathrm{D} \\
(46.9)\end{array}$ & $\begin{array}{c}10.50 \mathrm{D} \\
(50)\end{array}$ & $\begin{array}{c}16.96 \mathrm{~B} \\
(92.7)\end{array}$ & $\begin{array}{c}18.16 \mathrm{~A} \\
(92.7)\end{array}$ & \\
\hline
\end{tabular}

* $\%$ of tuberization are shown in bracts.

B. Microtuber yield $(\mathrm{mg}) / \mathrm{dish}$

\begin{tabular}{|c|c|c|c|c|c|c|}
\hline $\begin{array}{c}\text { CV. } \\
\text { Density }\end{array}$ & Sante & Safrane & Agria & Bolista & Provento & $\begin{array}{c}\text { Mean } \\
\text { Density }\end{array}$ \\
\hline $\mathbf{1 0}$ & $154.6 \mathrm{j}^{\star *}$ & $35.0 \mathrm{p}$ & $86.0 \mathrm{n}$ & $306.0 \mathrm{f}$ & $632.0 \mathrm{a}$ & $\mathbf{2 4 2 . 6} \mathrm{C}$ \\
$\mathbf{1 5}$ & $246.6 \mathrm{~h}$ & $125.0 \mathrm{~m}$ & $63.0 \mathrm{o}$ & $141.0 \mathrm{k}$ & $522.0 \mathrm{~b}$ & $\mathbf{2 1 9 . 5 \mathrm { D }}$ \\
$\mathbf{2 0}$ & $139.0 \mathrm{I}$ & $133.0 \mathrm{I}$ & $64.0 \mathrm{o}$ & $261.0 \mathrm{gh}$ & $514.0 \mathrm{bc}$ & $\mathbf{2 1 2 . 2 D E}$ \\
$\mathbf{2 5}$ & $158.3 \mathrm{j}$ & $273.0 \mathrm{~g}$ & $149.0 \mathrm{jk}$ & $315.0 \mathrm{ef}$ & $478.0 \mathrm{C}$ & $\mathbf{2 7 4 . 6 B}$ \\
$\mathbf{3 0}$ & $328.3 \mathrm{e}$ & $347.0 \mathrm{de}$ & $150.0 \mathrm{jk}$ & $357.0 \mathrm{~d}$ & $508.0 \mathrm{bc}$ & $\mathbf{3 3 8 . 1 A}$ \\
\hline Mean CV. & 205.36 C & 182.60D & $\mathbf{1 0 2 . 4 0 E}$ & $\mathbf{2 6 6 . 0 0 B}$ & $\mathbf{5 3 0 . 8 0 A}$ & \\
\hline
\end{tabular}

C. Ave. microtuber wt. (mg)

\begin{tabular}{|c|c|c|c|c|c|c|}
\hline CV. & Sante & Safran & Agria & Bolista & Provento & $\begin{array}{c}\text { Mean } \\
\text { Density }\end{array}$ \\
\hline $\mathbf{1 0}$ & $24.5 \mathrm{c}^{* *}$ & $14.4 \mathrm{i}$ & $14.97 \mathrm{~h}$ & $21.78 \mathrm{~d}$ & $34.0 \mathrm{~b}$ & $\mathbf{2 1 . 9 3 A}$ \\
$\mathbf{1 5}$ & $19.1 \mathrm{e}$ & $25.6 \mathrm{C}$ & $11.3 \mathrm{k}$ & $9.74 \mathrm{~m}$ & $43.38 \mathrm{a}$ & $\mathbf{2 1 . 8 2 A}$ \\
$\mathbf{2 0}$ & $15.9 \mathrm{gh}$ & $17.6 \mathrm{fg}$ & $10.6 \mathrm{kl}$ & $13.1 \mathrm{j}$ & $25.5 \mathrm{C}$ & $\mathbf{1 5 . 4 8 B}$ \\
$\mathbf{2 5}$ & $11.26 \mathrm{k}$ & $18.6 \mathrm{f}$ & $11.0 \mathrm{k}$ & $16.3 \mathrm{~g}$ & $19.0 \mathrm{e}$ & $\mathbf{1 5 . 2 3} \mathbf{B}$ \\
$\mathbf{3 0}$ & $16.1 \mathrm{gh}$ & $13.9 \mathrm{i}$ & $7.3 \mathrm{n}$ & $16.78 \mathrm{~g}$ & $20.0 \mathrm{~d}$ & $\mathbf{1 4 . 8 2 B C}$ \\
\hline Mean CV. & $\mathbf{1 7 . 3 8} \mathbf{B}$ & $\mathbf{1 6 . 9 4 B}$ & $\mathbf{1 1 . 6 3 D}$ & $\mathbf{1 5 . 5 4 C}$ & $\mathbf{2 8 . 3 2} \mathbf{A}$ & \\
\hline
\end{tabular}

\footnotetext{
** Means with the same letter for main effects and interactions are not significantly different at $5 \%$ level in tables A, B and C
} 
Table 2. Effect of single node explant density on $\%$ sprouted and rooted explants/petri dish in 5 potato cultivars.

A. \% of sprouted explants

\begin{tabular}{|c|c|c|c|c|c|c|}
\hline CV. & Sante & Safrane & Agria & Bolista & Provento & $\begin{array}{c}\text { Mean } \\
\text { Density }\end{array}$ \\
\hline Density & & & & & & \\
$\mathbf{1 0}$ & $63.3 \mathrm{~d}^{\star \star}$ & $66.6 \mathrm{~d}$ & $43.3 \mathrm{f}$ & $33.3 \mathrm{~g}$ & $60.0 \mathrm{de}$ & $\mathbf{5 3 . 3 0 \mathrm { E }}$ \\
$\mathbf{1 5}$ & $82.2 \mathrm{~b}$ & $53.3 \mathrm{e}$ & $88.8 \mathrm{~b}$ & $26.6 \mathrm{~h}$ & $55.5 \mathrm{e}$ & $\mathbf{6 1 . 3 0 D}$ \\
$\mathbf{2 0}$ & $61.6 \mathrm{~d}$ & $85.0 \mathrm{~b}$ & $75.0 \mathrm{C}$ & $85.0 \mathrm{~b}$ & $41.6 \mathrm{f}$ & $\mathbf{6 4 . 6 0 C}$ \\
$\mathbf{2 5}$ & $84.0 \mathrm{~b}$ & $92.0 \mathrm{a}$ & $94.6 \mathrm{a}$ & $88.0 \mathrm{~b}$ & $28.0 \mathrm{~h}$ & $\mathbf{7 7 . 3 0 B}$ \\
$\mathbf{3 0}$ & $88.8 \mathrm{~b}$ & $90.0 \mathrm{a}$ & $86.6 \mathrm{~b}$ & $86.6 \mathrm{~b}$ & $57.7 \mathrm{e}$ & $\mathbf{8 1 . 9 4 A}$ \\
\hline Mean CV. & $\mathbf{7 5 . 9 8 B}$ & $\mathbf{7 7 . 3 8 A}$ & $\mathbf{7 7 . 6 6 \mathrm { A }}$ & $\mathbf{6 3 . 9 C}$ & $\mathbf{4 8 . 8 6 \mathrm { D }}$ & \\
\hline
\end{tabular}

$\%$ of sprouted explants=No. of sprouted explant/total no. of explant x100 after 4 weeks in culture.

B. \% of rooted explants

\begin{tabular}{|c|c|c|c|c|c|c|}
\hline CV. & Sante & Safrane & Agria & Bolista & Provento & $\begin{array}{c}\text { Mean } \\
\text { Density }\end{array}$ \\
\hline $\mathbf{1 0}$ & $33.3 \mathrm{ef}^{\star \star}$ & $20.0 \mathrm{hi}$ & $26.6 \mathrm{~g}$ & $76.6 \mathrm{a}$ & $49.76 \mathrm{c}$ & $\mathbf{4 1 . 2 5} \mathbf{A}$ \\
$\mathbf{1 5}$ & $44.4 \mathrm{~cd}$ & $20.0 \mathrm{hi}$ & $26.6 \mathrm{~g}$ & $75.3 \mathrm{a}$ & $48.84 \mathrm{C}$ & $\mathbf{4 3 . 0 2} \mathbf{A}$ \\
$\mathbf{2 0}$ & $36.6 \mathrm{e}$ & $23.3 \mathrm{~h}$ & $31.6 \mathrm{ef}$ & $56.6 \mathrm{bc}$ & $43.28 \mathrm{~cd}$ & $\mathbf{3 8 . 2 7} \mathbf{B}$ \\
$\mathbf{2 5}$ & $17.3 \mathrm{i}$ & $44.0 \mathrm{~cd}$ & $45.3 \mathrm{c}$ & $48.0 \mathrm{c}$ & $43.98 \mathrm{~cd}$ & $\mathbf{3 9 . 7 1} \mathbf{B}$ \\
$\mathbf{3 0}$ & $37.7 \mathrm{e}$ & $28.8 \mathrm{~g}$ & $34.4 \mathrm{f}$ & $64.4 \mathrm{~b}$ & $42.60 \mathrm{~cd}$ & 33.06 C \\
\hline Mean CV. & 33.86B & $\mathbf{2 7 . 2 2 C}$ & 32.9B & $\mathbf{6 4 . 2 2 A}$ & $\mathbf{4 5 . 6 9 ~ A}$ & \\
\hline
\end{tabular}

$\%$ of rooted explants $=$ no rooted explant/total no. of explant $\times 100$

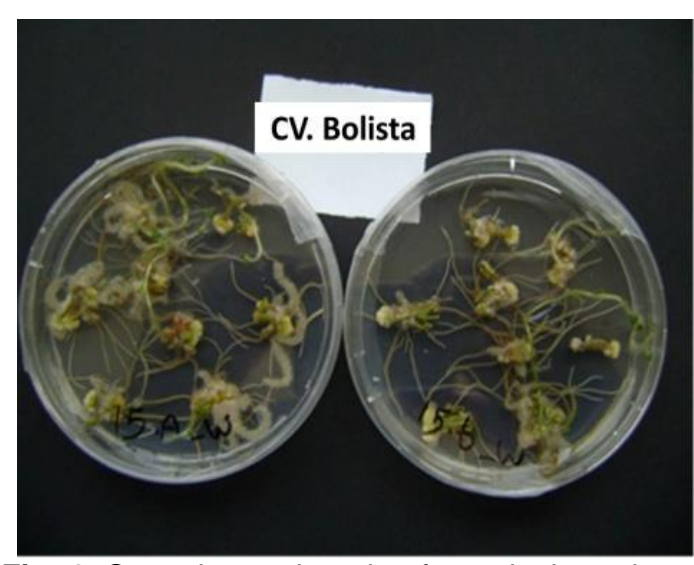

Fig. 1. Sprouting and rooting from single node explants.

largest \% of sprouted explants $(77.38 \%$ and $77.66 \%$, respectively), followed by cv. 'Sante', while the lowest percentages of sprouted explant were recorded in cv. 'Provento' (48.86\%), and followed by cv. 'Bolista' (63.9\%).

With respect to the interaction effect, results revealed that the highest \% sprouted explants was found in cv. 'Agria' (94.6\%) and 'Safrane' (92.0\%) at 25 explants/dish. At the highest explant density
(30 explants /dish), the cv. 'Safrane' also had $90 \%$ sprouted explants.

Potato single node explants were found toform roots in microtuber induction medium. The percentages of explants with roots are presented in Table (2B) for the main effects of explant density, cultivars and their interaction. Data indicated the reduction in \% rooted explant with the increase in explant density, from $44.25 \%$ at 10 explant/dish, to $33 \%$ at 30 explants/dish. Significant differences were also detected among potato cultivars for the formation of rooted explant. The cv. 'Bolista' recorded the highest percentage (64.2\%), while cv. 'Safrane' recorded the lowest \% of rooted explants (27.2\%).

The interaction of density $x$ cultivar was significant. The cv. 'Bolista' recorded the highest \% rooted explants (76.6 or $75.3 \%$ ) at 10 or 15 explants/dish, respectively. The lowest percent of rooted explants (17.3\%) was found in cv. 'Sante', with 25 explants/dish.

Experiment 2: Effect of planting density on microtuber production from in vitro plantlets

In this experiment, the production of potato microtubers was examined from plantlets grown in 
vitro on solid medium amended with a layer of liquid tuberization MS medium supplemented with 80 $\mathrm{g} / \mathrm{l}$ sucrose for two month in vitro under darkness at $20^{\circ} \mathrm{C}$. Six potato cultivars were tested under different plantlet density treatments $(5,10$, and 15 plantlets /jar).

Results of the main effect of density on microtuber number/jar and per plantlet are presented in Tables (3 and 4) and Fig. (2). Analysis of variance indicated significant effect of plantlet density/jar on microtuber number. Increasing plantlet density significantly increased the number of microtubers/jar from 13.15 microtubers at 5 plantlet/dish to 22.6 at 15 plantlet/jar. On per plantlet basis, the average number of microtubers per plantlet was significantly higher at 5 plantlet/jar (ave. $2.63 \mathrm{mi}-$ crotubers) compared to 15 plantlet/jar (ave. 1.52 microtuber) as shown in Table (4).

With respect to the main effect of cultivar, data indicated that the $\mathrm{cv}$. 'Universa' had the highest number of microtubers per jar (ave. 25.3) and per plantlet (ave. 2.67), followed by cv. 'Agria' (ave. 22.4 microtubers/jar) and per plantlet (ave. 2.77). The two cvs'Universa' and 'Agria' had the same number of microtubers/plantlet. The lowest average numbers of microtubers were recorded in cv. 'Provento'(ave. 14.3 microtubers/jar) and about 1.5 microtuber/plantlet (Table 3 and 4).

The interaction effect of plantlet density $x$ cultivars was significant. In the cvs.'Safrane', 'Diamant', 'Provento', 'Nicola' and 'Universa', the number of microtuber per jar increased with increasing plantlet density, while in cv. 'Agria', microtuber number per jar was higher (22.0 microtubers) at the lowest density compared to 18.0 microtubers/jar at the highest density.

The highest number of microtubers/jar was recorded in cv. 'Universa' which produced $33 \mathrm{mi}-$ crotubers at density of 15 plantlet/jars, while the least numbers of microtubers were found in cvs. 'Safrane', 'Diamant' and 'Provento'(about $9.3 \mathrm{mi}-$ crotubers/jar) at the lowest density (Table 3). At per plant basis, the highest microtuber number per plantlet was recorded in cv. 'Agria' (4.4 microtubers) at the lowest culture density, followed by $\mathrm{cv}$. 'Universa' (ave. 3.06 microtubers/plantlet) at the same density (Table 4).

Results presented in Table (3) indicated significant differences in microtuber yield with the increase in plantlet density from ave. $563.6 \mathrm{mg}$ at 5 plantlet/ jar to $1099 \mathrm{mg}$ at 15 plantlets/jar. However, on per plantlet basis, microtuber yield was higher at the lowest density, as compared with the yield at the highest plantlet density (Table 4).
The main effect of cultivars showed that the cv. 'Universa' had significantly the highest microtuber yield/jar (1684.4 mg) and per plantlet (174.3 mg) as showed in Tables (3) and (4), while the cv. 'Nicola' recorded the lowest microtuber yield.

The interaction of density $x$ cultivar significantly affected microtuber yield per jar and per plantlet. The highest microtuber yield per jar was recorded in cv. 'Universa' at the highest plantlet density which produced an average of $2554 \mathrm{mg}$ tubers/jar, followed by cv. 'Safran' which produced an average of $1745 \mathrm{mg}$ tubers/jar at the same planting density. The cv. 'Nicola' had the lowest microtuber yield $(260 \mathrm{mg} / \mathrm{jar})$ at the highest plantlet density.

Table 3. Effect of plantlet density on microtuber production per jarfrom 6 potato cultivars.

\begin{tabular}{|c|c|c|c|c|}
\hline \multicolumn{5}{|c|}{ Microtuber no./jar } \\
\hline $\begin{array}{l}\text { Density } \\
\text { cV. }\end{array}$ & 5 & 10 & 15 & Mean CV. \\
\hline Safrane & $9.30 \mathrm{f}$ & $17.30 \mathrm{de}$ & $22.5 \mathrm{c}$ & $16.3 \mathrm{D}$ \\
\hline Diamant & $9.33 f$ & $18.0 \mathrm{~d}$ & $20.6 c$ & $16.0 \mathrm{D}$ \\
\hline Agria & $22.0 \mathrm{c}$ & $27.0 \mathrm{~b}$ & $18.3 d$ & $22.4 \mathrm{~B}$ \\
\hline Provento & $9.33 \mathrm{f}$ & 13.3ef & $20.3 c$ & $14.3 \mathrm{E}$ \\
\hline Nicola & 13.66 ef & $18.6 \mathrm{~d}$ & $21.0 \mathrm{c}$ & $17.7 \mathrm{C}$ \\
\hline Universa & $15.33 \mathrm{e}$ & $27.6 \mathrm{~b}$ & $33.0 \mathrm{a}$ & $25.3 \mathrm{~A}$ \\
\hline $\begin{array}{c}\text { Mean } \\
\text { Density }\end{array}$ & $13.15 \mathrm{C}$ & $20.30 \mathrm{~B}$ & $22.61 \mathrm{~A}$ & \\
\hline \multicolumn{5}{|c|}{ Microtuber yield/jar $(\mathrm{mg})$} \\
\hline $\begin{array}{l}\text { Density } \\
\text { CV. }\end{array}$ & 5 & 10 & 15 & Mean CV. \\
\hline Safrane & 892.0 ef & $1160.0 \mathrm{~d}$ & $1745.0 \mathrm{~b}$ & $1265.6 \mathrm{~B}$ \\
\hline Diamant & $518.8 \mathrm{i}$ & $819.4 f$ & $591.90 \mathrm{~h}$ & $643.3 \mathrm{E}$ \\
\hline Agria & 1025.4 de & $988.2 \mathrm{e}$ & $558.6 \mathrm{gh}$ & 857.4 D \\
\hline Provento & $407.80 \mathrm{jk}$ & $589.5 \mathrm{~h}$ & 872.5 ef & $934.9 \mathrm{C}$ \\
\hline Nicola & $435.4 j$ & $507.30 \mathrm{i}$ & $260.0 \mathrm{k}$ & $400.9 \mathrm{~F}$ \\
\hline Universa & $1027.1 \mathrm{de}$ & $1472.0 \mathrm{c}$ & $2554.1 \mathrm{a}$ & $1684.5 \mathrm{~A}$ \\
\hline $\begin{array}{c}\text { Mean } \\
\text { Density }\end{array}$ & $563.68 \mathrm{C}$ & 922.73 B & 1097.0 A & \\
\hline \multicolumn{5}{|c|}{ Average microtuber wt./microtuber (mg) } \\
\hline $\begin{array}{l}\text { Bensity } \\
\text { CV. }\end{array}$ & 5 & 10 & 15 & Mean CV. \\
\hline Safrane & $95.90 \mathrm{a}$ & $66.94 \mathrm{~b}$ & $77.55 \mathrm{~b}$ & $80.13 \mathrm{~A}$ \\
\hline Diamant & $55.58 \mathrm{~d}$ & $45.52 \mathrm{e}$ & $28.64 \mathrm{hi}$ & $43.25 \mathrm{C}$ \\
\hline Agria & $46.61 \mathrm{e}$ & $36.60 \mathrm{~g}$ & $30.47 \mathrm{~h}$ & $37.89 \mathrm{D}$ \\
\hline Provento & $43.70 \mathrm{f}$ & $44.21 \mathrm{f}$ & $42.91 \mathrm{f}$ & $43.60 \mathrm{C}$ \\
\hline Nicola & $31.86 \mathrm{gh}$ & $27.18 \mathrm{i}$ & $12.38 \mathrm{j}$ & $23.80 \mathrm{E}$ \\
\hline Universa & $67.00 \mathrm{c}$ & $53.1 \mathrm{~d}$ & $77.39 \mathrm{~b}$ & $65.80 \mathrm{~B}$ \\
\hline $\begin{array}{c}\text { Mean } \\
\text { Density }\end{array}$ & $56.77 \mathrm{~A}$ & $45.59 \mathrm{~B}$ & 44.89 BC & \\
\hline
\end{tabular}

** Means with the same letter for main effects and interactions are not significantly different at $5 \%$ level 
Table 4. Effect of plantlet density on microtuber number and yield per plantlet in six potato cultivars.

\begin{tabular}{|c|c|c|c|c|}
\hline \multicolumn{5}{|c|}{ Microtuber no./plantlet } \\
\hline CV. Density & 5 & 10 & 15 & Mean CV. \\
\hline Safrane & 1.86 & 1.73 & 1.50 & $1.696 \mathrm{D}$ \\
\hline Diamant & 1.86 & 1.80 & 1.37 & $1.676 \mathrm{D}$ \\
\hline Agria & 4.40 & 2.7 & 1.22 & $2.77 \mathrm{~A}$ \\
\hline Provento & 1.86 & 1.33 & 1.35 & $1.513 \mathrm{DE}$ \\
\hline Nicola & 2.73 & 1.86 & 1.53 & $2.106 \mathrm{C}$ \\
\hline Universa & 3.06 & 2.76 & 2.20 & $2.673 \mathrm{~B}$ \\
\hline Mean Density & $2.63 \mathrm{~A}$ & $2.03 \mathrm{~B}$ & $1.52 \mathrm{C}$ & \\
\hline \multicolumn{5}{|c|}{ Microtuber yield mg/plantlet } \\
\hline CV. Density & 5 & 10 & 15 & Mean CV. \\
\hline Safrane & 178.40 & 116.00 & 116.33 & $136.91 \mathrm{~B}$ \\
\hline Diamant & 103.76 & 81.94 & 39.46 & 75.05 D \\
\hline Agria & 205.08 & 98.82 & 37.24 & $113.71 \mathrm{C}$ \\
\hline Provento & 81.56 & 58.92 & 58.16 & $66.21 \mathrm{E}$ \\
\hline Nicola & 87.08 & 50.73 & 17.33 & $51.71 \mathrm{~F}$ \\
\hline Universa & 205.42 & 147.20 & 170.27 & 174.29 A \\
\hline Mean Density & 143.55A & 92.27 B & $73.13 \mathrm{C}$ & \\
\hline
\end{tabular}

Different response of potato cultivars to the planting density treatments was observed. In this respect, the cvs.'Safrane', 'Provento' and 'Universa' produced higher microtuber yield with each increase in density, while in cv. 'Agria', microtuber yield decrease with the increase in plantlet density per jar (Table 3). In all cultivars, the yield of microtuber per plantlet decreased with the increase in plantlet density/jar as shown in Table (4).

Results shown in Table (3) indicated that planting density significantly affected microtuber weight. At the lowest density, microtuber had higher weight than at the highest density (56.7 mg vs. $44.8 \mathrm{mg}$ ). Difference among potato cvs.in microtuber weight was also detected. The cv. 'Safrane' recorded the highest average microtuber weight $(80.1 \mathrm{mg})$ followed by cv. 'Universa' (ave. $65.8 \mathrm{mg}$ ), while the cv. 'Agria' recorded the lowest microtuber weight (37.9 mg). The interaction of density $x$ cultivar was significant, and the highest microtuber weight was found in cv. 'Safrane' (95.9 mg) at the lowest culture density (Table 3 ). In most potato cultivars, average microtuber weight decreased with the increase in plantlet density/jar, except in cv. 'Universa'.

\section{Experiment 3: Effect of explant source on pota- to microtuberization in petri dish}

In this experiment, plantlets from 5 potato cultivars; 'Diamant', 'Nicola', 'Agria', 'Universa' and 'Spunta' were removed from 4 weeks old cultures and sectioned from different position viz; 3-nodes segment from the plantlet top (L/T), 3-nodes segment from the base $(\mathrm{L} / \mathrm{B}), 6$-single nodes from the top, and 6-single nodes from the base of the plantlet. The four different explant sources were cultured (layered on the medium surface) in petri dishes containing microtuberization medium (MS + $80 \mathrm{~g} / \mathrm{l}$ sucrose) and incubated at $20^{\circ} \mathrm{C}$ in the dark for 8 weeks.

Results of the main effects of explant source, cultivars and their interaction on number of microtuber per dish are presented in Table (5). Significant differences among means of explant source treatments were observed, where explants derived from single nodes from top part of the plantlets produced more microtubers (3.34/dish) than the other tested explant sources. The main effect of cultivar was also significant and the cv. 'Diamant' produced more microtubers (ave. 3.6) than the other examined cultivars under the conditions of this experiment (Fig. 3).

The interaction of explant source $x \mathrm{cv}$. significantly affected microtuber number. The culture of single node explants taken from the top of the plantlet of cv. 'Diamant' produced the highest number of microtubers (8.0/dish).

Table 5. Effect of explant source on microtuber No./dish in five potato cultivars.

\begin{tabular}{|c|c|c|c|c|c|}
\hline $\begin{array}{c}\text { Explant } \\
\text { CV. }\end{array}$ & $L / T^{*}$ & $L / B^{*}$ & $\mathbf{S} / \mathbf{T}^{\star}$ & $S / B^{*}$ & Mean CV. \\
\hline Diamant & $1.8 e^{\star *}$ & $2.0 \mathrm{~d}$ & $8.0 \mathrm{a}$ & $2.66 \mathrm{bc}$ & $3.6 \mathrm{~A}$ \\
\hline Nicola & $1.0 \mathrm{f}$ & $3.0 \mathrm{~b}$ & $2.5 d$ & $2.0 \mathrm{~d}$ & $2.13 \mathrm{BC}$ \\
\hline Agria & $1.5 \mathrm{e}$ & $3.0 \mathrm{~b}$ & $2.5 \mathrm{~d}$ & $2.0 \mathrm{~d}$ & $2.25 \mathrm{~B}$ \\
\hline Universa & $1.0 \mathrm{f}$ & $1.0 \mathrm{f}$ & $1.5 \mathrm{e}$ & $3.0 \mathrm{~b}$ & 1.63 DE \\
\hline Spunta & $1.75 \mathrm{~d}$ & $1.33 \mathrm{e}$ & $2.2 \mathrm{~d}$ & $2.0 \mathrm{~d}$ & $1.8 \mathrm{D}$ \\
\hline Mean & $1.41 \mathrm{D}$ & 2.06 & $3.34 \mathrm{~A}$ & $2.33 \mathrm{~B}$ & \\
\hline Explant & & BC & & & \\
\hline
\end{tabular}

${ }^{*} \mathrm{~L} / \mathrm{T}=3$ node-layer from top, $\mathrm{L} / \mathrm{B}=3$ node-layer from base, $\mathrm{S} / \mathrm{T}=$ single nodes from top, $\mathrm{S} / \mathrm{B}=$ single node from the base.

${ }^{* *}$ Means with the same letter with in columns and rows are not significantly different at $5 \%$ level 


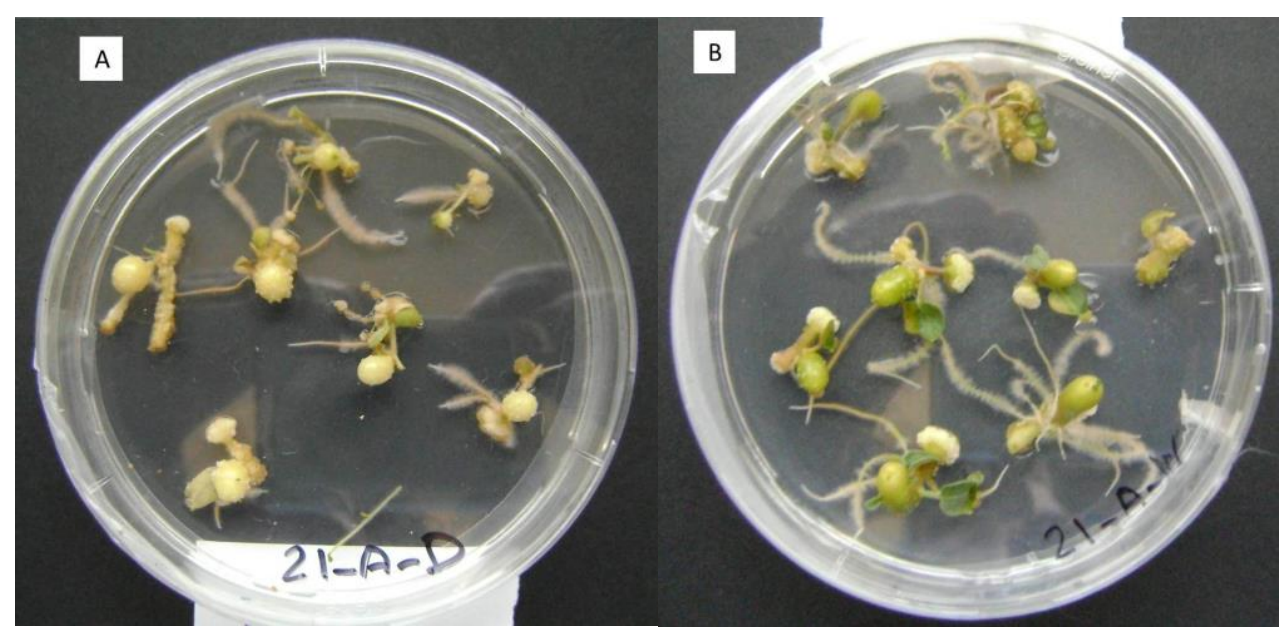

Fig. 3. Effect of explant source from Apical (A) and Basel part (B) on microtuber formation.

The yield of microtubers (mg/dish) was significantly affected by explant source (Table 6). The use of single node explants derived from plantlet top part significantly produced the highest microtuber yield (205.5 mg/dish) compared to $104.8 \mathrm{mg} / \mathrm{dish}$ using 3-nodal segments from the top. Significant variations among the tested cultivars were detected where the cv. 'Diamant' produced the highest microtuber yield (343 mg/dish), followed by cv. 'Universa' (132.8 $\mathrm{mg} / \mathrm{dish})$, while the least yield was found in cv. 'Agria' and 'Spunta' (49 mg/dish).

Table 6. Effect of explants source on microtuber yield mg./dish.

\begin{tabular}{|c|c|c|c|c|c|}
\hline Explant & $\mathbf{L} / \mathbf{T}^{\star}$ & $\mathrm{L} \mathbf{B}^{*}$ & $\mathbf{S} / \mathbf{T}^{\star}$ & $\mathbf{S} / \mathbf{B}^{*}$ & $\begin{array}{c}\text { Mean } \\
\text { CV. }\end{array}$ \\
\hline Diamant & $189.1 \mathrm{~cd}$ & $217.6 \mathrm{c}$ & $850.4 \mathrm{a}$ & $115.3 \mathrm{~d}$ & $343.0 \mathrm{~A}$ \\
\hline Nicola & $112.1 \mathrm{~d}$ & $192.4 \mathrm{~cd}$ & $36.25 i$ & $32.5 \mathrm{i}$ & $93.3 \mathrm{C}$ \\
\hline Agria & $50.1 \mathrm{~g}$ & $88.2 \mathrm{e}$ & $36.05 \mathrm{i}$ & $23.1 \mathrm{j}$ & 49.35 D \\
\hline Universa & $53.4 \mathrm{~g}$ & $68.4 \mathrm{f}$ & $66.55 \mathrm{f}$ & $343.0 \mathrm{~b}$ & $132.8 \mathrm{~B}$ \\
\hline Spunta & $48.7 \mathrm{~h}$ & $62.4 \mathrm{f}$ & $43.3 \mathrm{~h}$ & $41.77 \mathrm{hi}$ & $49.0 \mathrm{D}$ \\
\hline $\begin{array}{c}\text { Mean } \\
\text { Explant }\end{array}$ & 104.8D & 125.8B & 206.5 A & $111.13 \mathrm{C}$ & \\
\hline
\end{tabular}

${ }^{*} \mathrm{~L} / \mathrm{T}=3$ node-layer from top, $\mathrm{L} / \mathrm{B}=3$ node-layer from base, $\mathrm{S} / \mathrm{T}=$ single nodes from top, $S / B=$ single node from the base

${ }^{* *}$ Means with the same letter within columns and rows are not significantly different at $5 \%$ level

Microtuber yield was significantly affected by the interaction between explant source $x$ cultivar. The highest yield was obtained in cv. 'Diamant' using single node explants from the top (850.4 $\mathrm{mg} / \mathrm{dish}$ ), followed by cv. 'Diamant' using single nodes from the base (ave. $343 \mathrm{mg} / \mathrm{dish}$ ), while the least yield was obtained from single nodes taken from the base of plantlet in cv. 'Agria' (23.1 $\mathrm{mg} /$ dish).

Results of ANOVA indicated that the highest average microtuber weight was recorded using 3node layered segment from the plantlet base ( 63.5 $\mathrm{mg} /$ microtuber), while the least microtuber weight was found in explants derived from single nodes of the plantlet top part (39.8 $\mathrm{mg} /$ microtuber) as shown in Table (7).

With respect to the main effect of potato cultivars, the $\mathrm{cv}$. Diamant recorded significantly the highest average microtuber weight $(90.85 \mathrm{mg} / \mathrm{mi}-$ crotuber), followed by cv. 'Universa' $(70.1 \mathrm{mg} / \mathrm{mi}-$ crotuber), while the $\mathrm{cv}$. 'Agria' had the least microtuber weight $(19.0 \mathrm{mg}$ ). Data also revealed that the interaction of explant source $x$ cultivar was significant (Table 7). The highest microtuber weight was recorded in cv. 'Universa' (114.3 mg/microtuber) using single node explants from the basal parts of their plantlets, followed by cv. 'Diamant' using L/T, $\mathrm{L} / \mathrm{B}$ or $\mathrm{S} / \mathrm{T}$ explants. The least recorded average microtuber weight was found in cv. 'Agria' (11.5 $\mathrm{mg} / \mathrm{mic}$ rotuber) using single nodes from the base (S/B).

\section{Experiment 4: Effect of explant source on pota- to microtuberization in glass jars}

In this experiment, the different explant sources examined in the previous experiment were tested, in addition to using complete sixnodes layered 
plantlet from two potato cvs.'Nicola' and 'Arinda'. The in vitro culture was carried out in $300 \mathrm{ml}$ ca. glass jars instead of petri dishes. Medium components and incubation condition were similar to experiment 4 .

Table 7. Effect of explant source on average microtuber wt. (mg).

\begin{tabular}{|c|c|c|c|c|c|}
\hline cv. Explant & $\mathbf{L} / \mathbf{T}^{\star}$ & $L / B^{*}$ & $\mathbf{S} / \mathbf{T}^{\star}$ & $S / B^{*}$ & $\begin{array}{c}\text { Mean } \\
\text { CV. }\end{array}$ \\
\hline Diamant & $105.0 \mathrm{~b}$ & $108.8 \mathrm{~b}$ & $106.3 \mathrm{~b}$ & $3.3 \mathrm{e}$ & $\begin{array}{c}90.85 \\
\text { A }\end{array}$ \\
\hline Nicola & $12.1 \mathrm{j}$ & $64.1 \mathrm{c}$ & $14.4 \mathrm{ij}$ & $16.25 \mathrm{i}$ & $27.5 \mathrm{C}$ \\
\hline Agria & $33.3 f$ & $29.4 \mathrm{~g}$ & $14.4 \mathrm{ij}$ & $11.55 \mathrm{j}$ & $19.0 \mathrm{D}$ \\
\hline Universa & $53.4 \mathrm{~d}$ & $68.4 \mathrm{c}$ & $44.4 \mathrm{e}$ & $114.3 \mathrm{a}$ & $70.1 \mathrm{~B}$ \\
\hline Spunta & $27.8 \mathrm{~g}$ & $46.9 \mathrm{e}$ & $19.7 \mathrm{~h}$ & $20.88 \mathrm{~h}$ & $28.8 \mathrm{C}$ \\
\hline $\begin{array}{c}\text { Mean } \\
\text { Explant }\end{array}$ & $6.3 \mathrm{~B}$ & $63.5 \mathrm{~A}$ & $39.8 \mathrm{C}$ & $41.25 B C$ & \\
\hline
\end{tabular}

${ }^{*} \mathrm{~L} / \mathrm{T}=3$ node-layer from top, $\mathrm{L} / \mathrm{B}=3$ node-layer from base $\mathrm{S} / \mathrm{T}=$ single nodes from top, $\mathrm{S} / \mathrm{B}=$ single node from the base. ${ }^{* *}$ Means with the same letter with in columns and rows are not significantly different at $5 \%$ level

Results of the main effect of explant source, cultivar and their interaction on number of microtuber/jar are presented in Table (8). Results indicated that the culture of 2 plantlet segments per jar each containing 3 nodes $(\mathrm{L} / \mathrm{T})$ and taken from the plantlet top, or the culture of single nodes from the top, each had significantly the largest number of microtubers/jar (2.5 or $2.25 /$ jar, respectively), followed by single nodes from the plantlet base (ave. 2.0 microtuber/jar). The least microtuber number was detected using either layer of complete plantlet or 3-nodes layer from the base (ave1.25 microtuber/jar). The cv. 'Arinda' had formed more microtuber/jar than cv. 'Nicola'. The interaction effect of explant source $x$ cultivar was significant. The highest recorded number of microtuber/jar was found in cv. 'Arinda' under both L/T or S/B treatments, while the lowest number was detected in cv.'Nicola' un$\operatorname{der} \mathrm{L} / \mathrm{B}$ or $\mathrm{S} / \mathrm{B}$.

With regard to the main effect of explant source, cultivar and their interaction on microtuber yield, results shown in Table (8) indicated that the culture of layered complete plantlet having 6 nodes resulted in the highest microtuber yield/jar (ave. $202.2 \mathrm{mg} / \mathrm{jar}$ ) followed by culturing single nodes from the top (166.7 mg/jar) or 3-nodes layered from the top ( $162.2 \mathrm{mg} / \mathrm{jar}$ ) while single nodes from the base produced the lowest microtuber yield (ave.52.7 mg/jar). The cv. 'Nicola' produced significantly much were yield $(228.2 \mathrm{mg} / \mathrm{jar})$ than $\mathrm{cv}$. 'Arinda'.
The interaction of explant source $x \mathrm{cv}$. was significant and the highest microtuber yield was recorded in cv. 'Nicola' (384.4 mg/jar) using complete plantlet layered on the surface of microtuberization medium.

Regarding the main effect of explant source, cultivar and their interaction on the average microtuber weight, results in Table (8) clearly demonstrated that the culture of complete plantlet significantly produced the highest average microtuber weight (138 $\mathrm{mg} / \mathrm{microtuber}$ ) as compared to the other explant source. The cv. 'Nicola' produced significantly heavier microtuber $(146.1 / \mathrm{mg} / \mathrm{micro}-$ tuber) compared to the cv. 'Arinda' (ave. $32.3 \mathrm{mg} /$ microtuber).

The effect of the interaction of explant source $x$ cultivar revealed that the cv. 'Nicola' produced microtuber with the highest weight (ave. $256.2 \mathrm{mg}$ ) with the culture of complete plantlet.

\section{Experiment 5: Effect of potato genotypes on microtuberization}

In the previous in vitro experiments, several treatments were tested for their effect on potato microtuberization potential using some potato genotypes to examine their different responses to the treatments. In this experiment, ten potato cultivars were tested for their microtuberization in a simple CRD experiment, aside from the interaction effects. Plantlets (5 per jar) were grown on solid MS microtuberization medium for 2 weeks; the liquid microtuberization medium was added to each jar and incubated in the dark at $20^{\circ} \mathrm{C}$ for 8 weeks. The effects of potato genotypes on number and yield of microtuber/jar, as well as the average microtuber weight and diameter are shown in Table (9).

With respect to the effect of genotypes on number of microtuber /jar, results indicated that the cv. 'Safran' had the highest number of microtuber (7.76 microtubers/jar) and per plantlet (1.55/ plantlet) followed by cv. 'Nicola' (7.23 microtubers/jar and 1.44 /plantlet) while the $\mathrm{cv}$. 'Arinda' produced the lowest number (ave.2.33 per jar) a followed by cv. 'Agria' (2.63 microtubers /jar).

With respect to the effect of potato genotypes on microtuber yield, results of Table (9). showed that the cv. 'Safrane' significantly outperformed all other cultivars in microtuber yield (1055 mg/jar and $211 \mathrm{mg} /$ plantlet). The cv. 'Nicola' came the second, while cv. 'Agria'was the least in microtuber yield.

Regarding average microtuber weight, results of ANOVA indicated that cv. 'Arinda' had the largest average microtuber weight (ave. $147.6 \mathrm{mg}$ ), 
Table 8. Effect of explant sources on microtuber production in vitrofrom two potato cultivars grown in jars.

\begin{tabular}{|c|c|c|c|c|c|c|c|c|c|}
\hline & \multicolumn{3}{|c|}{ Microtuber no./jar } & \multicolumn{3}{|c|}{ Microtuber yield $(\mathrm{mg}) / \mathrm{jar}$} & \multicolumn{3}{|c|}{ Ave. microtuber wt.(mg) } \\
\hline $\begin{array}{l}\text { CV. } \\
\text { Explant }\end{array}$ & Nicola & Agria & Mean Exp. & Nicola & Agria & Mean Exp. & Nicola & Agria & Mean Exp. \\
\hline Layer/T & $2.0 b^{*}$ & $3.0 \mathrm{a}$ & $2.5 \mathrm{~A}$ & $227.3 \mathrm{c}$ & $97.1 \mathrm{e}$ & $162.2 \mathrm{~B}$ & $113.6 \mathrm{bc}$ & $32.4 \mathrm{~h}$ & $73.0 \mathrm{C}$ \\
\hline Layer/B & $1.0 \mathrm{~d}$ & $1.5 \mathrm{c}$ & 1.2 & $216.7 d$ & $62.2 \mathrm{~g}$ & $139.5 \mathrm{C}$ & $216.7 b$ & $41.4 \mathrm{~g}$ & $129.0 \mathrm{~B}$ \\
\hline Single/T & $3.0 \mathrm{a}$ & $1.5 \mathrm{c}$ & $2.25 \mathrm{~A}$ & $255.9 b$ & $77.4 f$ & 166.7 B & $85.3 d$ & 51.6 ef & 68.4 CD \\
\hline Single/B & $1.0 \mathrm{~d}$ & $3.0 \mathrm{a}$ & $2.00 \mathrm{~B}$ & $56.8 \mathrm{~h}$ & $48.2 \mathrm{hi}$ & $52.7 \mathrm{D}$ & $58.6 \mathrm{e}$ & $16.2 \mathrm{ij}$ & $37.4 \mathrm{E}$ \\
\hline Complete & $1.5 \mathrm{c}$ & $1.0 \mathrm{~d}$ & $1.25 \mathrm{C}$ & $384.4 a$ & $19.9 \mathrm{j}$ & $202.2 \mathrm{~A}$ & $256.2 \mathrm{a}$ & $19.9 \mathrm{i}$ & $138.0 \mathrm{~A}$ \\
\hline Mean CV. & $1.7 \mathrm{~B}$ & $2.0 \mathrm{~A}$ & & 228.2A & $61.0 \mathrm{~B}$ & & 146.1 A & $32.3 \mathrm{~B}$ & \\
\hline
\end{tabular}

*Means with the same letter with in columns and rows are not significantly different at $5 \%$ level

Table 9. Potato microtuber production from plantlets as affected by genotypes (solid/liquid medium).

\begin{tabular}{|c|c|c|c|c|c|c|}
\hline \multirow{2}{*}{ CV. } & \multicolumn{2}{|c|}{ Microtuber number } & \multicolumn{2}{|c|}{ Microtuber yield(mg)/jar } & $\begin{array}{c}\text { Average mi- } \\
\text { crotuber } \\
\text { weight (mg.) }\end{array}$ & $\begin{array}{c}\text { Microtuber } \\
\text { diameter(mm) }\end{array}$ \\
\cline { 2 - 5 } & Per jar & Per plantlet ${ }^{\star \star}$ & Per jar & Per plantlet $^{\star \star}$ & \\
\hline Safrane & $7.76 \mathrm{a}^{\star}$ & 1.552 & $1055.0 \mathrm{a}$ & 211.0 & $124.8 \mathrm{~b}$ & $4.79 \mathrm{~b}$ \\
Diamant & $4.26 \mathrm{c}$ & 0.852 & $249.0 \mathrm{e}$ & 49.8 & $59.0 \mathrm{~g}$ & $4.32 \mathrm{c}$ \\
Spunta & $5.53 \mathrm{~b}$ & 1.106 & $339.6 \mathrm{~d}$ & 67.8 & $64.7 \mathrm{f}$ & $4.04 \mathrm{~cd}$ \\
Triomph & $3.10 \mathrm{de}$ & 0.620 & $225.7 \mathrm{ef}$ & 45.0 & $81.7 \mathrm{e}$ & $4.78 \mathrm{~b}$ \\
Nicola & $7.23 \mathrm{ab}$ & 1.446 & $639.3 \mathrm{~b}$ & 127.8 & $101.2 \mathrm{c}$ & $3.64 \mathrm{~d}$ \\
Universa & $3.53 \mathrm{~d}$ & 0.706 & $376.3 \mathrm{~cd}$ & 75.2 & $126.9 \mathrm{~b}$ & $3.63 \mathrm{~d}$ \\
Agria & $2.63 \mathrm{e}$ & 0.526 & $113.6 \mathrm{f}$ & 22.6 & $56.6 \mathrm{~g}$ & $3.92 \mathrm{~d}$ \\
Provento & $4.66 \mathrm{C}$ & 0.932 & $392.0 \mathrm{c}$ & 78.4 & $92.5 \mathrm{~cd}$ & $5.66 \mathrm{a}$ \\
Arinda & $2.23 \mathrm{ed}$ & 0.446 & $348.0 \mathrm{~d}$ & 69.6 & $147.6 \mathrm{a}$ & $3.67 \mathrm{~d}$ \\
Bolista & $5.60 \mathrm{~b}$ & 1.120 & $227.6 \mathrm{ef}$ & 45.4 & $43.2 \mathrm{~h}$ & $4.52 \mathrm{bc}$ \\
\hline
\end{tabular}

${ }^{*}$ Means with the same letters in each column are not significantly different according to LSD test at $5 \%$.

** Estimated values

followed by cv. 'Universa' (126.9 mg/microtuber) and cv. 'Safrane' (124.8 $\mathrm{mg} / \mathrm{microtuber})$. The cv. 'Bolista' recorded the lowest microtuber weight (43.2 $\mathrm{mg} / \mathrm{microtuber}$ ), followed by $\mathrm{cv}$. 'Diamant' (59.0 mg) and 'Agria' (56.6 mg/microtuber).

Microtuber diameter was significantly different among the tested genotypes (Table 9). Potato cv. 'Provento' had microtubers with largest diameter (ave. $5.66 \mathrm{~mm}$ ), followed by the microtubers from cv. 'Safrane' (ave. $4.79 \mathrm{~mm}$ ), 'Triomph' (ave. 4.78 $\mathrm{mm}$ ) and cv. 'Bolista' (4.52 mm). The rest of cultivar had microtubers with on average diameter between $3.32 \mathrm{~mm}$ to $4.0 \mathrm{~mm}$.

\section{DISCUSSION}

Results of the first study concerning the in vitro microtuber induction and development as affected by single node inoculum density indicated increase in number and yields of microtubers at high density per petri dish, whereas, at low density the average microtuber weight was higher. It was also observed that the \% sprouted nodes in culture increased from $\% 53$ at low density to $\% 82$ at high density. However, percent rooted explants decreased at high density. Previous research indicated positive correlation between microtuber number and microtuber yield, therefor; the increase yield at high density may be due to increased microtuber number in addition to increase \% tuberization. The increase \% rooted explants at low density may lead to increase competition between different induced organs (roots and microtuber developed from the nodal bud), a possible reason for reduced microtuber yield at low inoculum density. In addition, the increase sprouting at high density may explain the reduced average microtuber weight at high density, and the competition for nutrients in the medium.

The decrease mean of microtuber weight at high single node planting density is in accordance with the results of Nikopoulos (1993), at high density, only $0.75 \mathrm{ml}$ of medium is available to each explant, while at the lowest density, $4 \mathrm{ml}$ is available which may also explain the higher microtuber FW at low density. However, in contrast to our re- 
sults, Nikopoulos (1993) did not find significant differences between low and high single node explant inoculum densities in microtuberization, since we used higher sucrose level (\%8) compared with $\% 6$ sucrose in his microtuberization medium.

Microtuber production from plantlets in vitro is also a well-established protocol. The effects of different plantlet densities (5, 10 and 15 plantlets / jar) were also studied and results were similar to those obtained with the culture of single nodes. In this respect, microtuber number and yield increased, and mean microtuber FW decreased at higher planting density. However, number and yield of microtuber per plantlet was lower at the highest planning density.

The reduced average microtuber $\mathrm{FW}$ at high density may be related to the increased competition among plantlets for nutrients and sucrose uptake from the medium. Tabori et al (2000) reported increase in number of large microtubers with the increase in culture density, may be due to using larger vessels. Mohamed and Shabaan (1995) found that most medium $\mathrm{N}$ and $\mathrm{K}$ are taken up during early phase of microtuber induction from plantlet. Therefore, at high density planting, competition among plantlet for nutrients will leads to reduced microtuber size, but not their number/jar.

Results of the main effects of explant source indicated that single nodes taken from the top of the plantlets produced more microtubers than those taken from the base or from 3-nodes segment, with more than $50 \%$ tuberization. The highest microtuber number was recorded in cv. 'Diamant', with the highest recorded \% tuberization (\%133), indicating significant genotypic/explant source effect. Nodes from the top also produced the highest microtuber yield. These results indicated close relationship between microtuber number and yield. Sing nodes from the plantlet top part may have more endogenous promoter levels, or they may be the first portion of the plantlet receiving the low temperature signal affecting microtuber induction. In support of this conclusion, auxin level was reported to increase during tuber formation and remain high during microtuber growth as cited by Roumeliotis et al (2012). The promotive effect of auxin and cytokinin on the in vitro tuberization was also reported by Mohamed et al (1992) in MS medium at high sucrose level. The cytokinin riboside increased during tuberization (Matsuo et al 1988). It was suggested by Melis and Van Staden (1985) that cytokinins may play a role in transport and accumulation of carbohydrates, accompanied by cell enlargement in tubers.
Results are in agreement with those of Wang and Langille (2007) who noticed the induction of microtubers from 2-node apical cuttings under inductive or none inductive conditions. Fatima et al (2005) reported increase number and yield of microtubers using single nodes than multiple node segments or shoot tips, similar to the results of Kanwal et al (2006). However, the early report of Nowak and Colborne (1989) indicated that node position on the plantlet taken from the sub-apical, medial or basal parts were not significantly different in microtuber number or FW, although explants from the basal part produced lower number of microtubers.

Repeating of the experiment in glass jars using complete 6-nodes plantlet, our results showed that 3-node segment from the top or single node from the top produced larger number of microtubers than those taken from the base, which agree with the previous experiment. However, the culture of layered complete plantlets (without shoot tip or roots) produced the highest microtuber number and yield/jar, followed by single nodes from the top. It was also shown by Leclerc et al (1994) that layered plantlets produced more microtubers/vessel than nodal cuttings. Results of Struik (1999) showed improved microtuber induction on explants most distance from illuminated leaves on the plantlet top. However, our cultures were incubated at darkness which may explain the different findings. The increase tuberization from complete plantlets may be the result of increase the length of the plantlet segment exposed to the medium and better uptake of nutrients, as concluded by $\mathrm{Pa}$ pathanasiou et al (1994) who found that increasing the length of nodal explants from 4 to $16 \mathrm{~mm}$ increased \% tuberization and microtuber weight.

In conclusion, when the mass production of potato in vitro microtuberization capacity was tested through the examination of explant planting density and source in different newly-introduced potato cultivars, results indicated significant promotive effects of increasing explant densities from single nodes or whole 6-node plantlets on microtuber number and yield, while microtuber fresh weight was increased with low inoculum density. The culture of single nodes taken from the top part of the plantlet produced higher number and yield, but lower microtuber fresh weight than those taken from the base or the 3-node segment. Among the 10 evaluated potato cultivars, the new cv. 'Safrane' produced the highest number and yield of microtubers per jar or per plantlet. 


\section{REFERENCES}

Ahmadian, S.H. and Zarghami, R. 1998. The effect of different positions of nodes on the production of microtubers from tissue culture plantlets. Proc. the $5^{\text {th }}$ Iranian Crop Sci. Cong. Karaj, pp. 196-197.

Aryakia, E. and Hamidoghli, Y. 2010. Comparison of kinetin and 6-banzyl amino purine effect on in vitro microtuberization of two cultivars of potato (Solanum tuberosum L.). Amer. Eur. J. Agri. Environ. Sci., 8, 710-714.

Escalante, B.Z. and Langille, A.R. 1998. Photoperiod, temperature, gibberellin, and an antigibberellin affect tuberization of potato stem segments in vitro. HortScience, 33(4), 701703.

Fatima, B., Usman, M., Ahmad, I. and Khan, I.A. 2005. Effect of explant and sucrose on microtuber induction in potato cultivars. Int. J. Agri. Biol., 7(1), 63-66.

FAOSTAT. 2012. FAOSTAT. Food and Agriculture Organization of the United Nations, Rome, Italy. (http://faostat.fao.org).

Garner, N. and Blake, J. 1989. The induction and development of potato microtubers in vitro on media free of growth regulating substances. Annals of Botany, 63(6), 663-674.

Kanwal, A., Ali, A. and Shoaib, K. 2006. In vitro microtuberization of potato (Solanum tuberosum L.) cultivar kuroda-A new variety in Pakistan. International Journal of Agriculture and Biology, 8(3), 337-340.

Leclerc, Y., Donnelly, D.J. and Seabrook, J.E. 1994. Microtuberization of layered shoots and nodal cuttings of potato: The influence of growth regulators and incubation periods. Plant Cell, Tissue and Organ Culture, 37(2), 113120.

Levy, D., Fogelman, E., Levine, A. and Itzhak, Y. 1995.Tuberization in vitro and dormancy of potato (Solanum tuberosum L.) microtubers. In Current Issues in Plant Molecular and Cellular Biology (pp. 123-125). Springer Netherlands.

Matsuo, T., Mitsuzono, H., Okada, R. and Itoo, S. 1988. Variations in the levels of major free cytokinins and free abscisic acid during tuber development of sweet potato. Journal of Plant Growth Regulation, 7(4), 249-258.

Melis, R.J.M. and Van Staden, J. 1985. Tuberization in cassava (Manihotesculenta): cytokinin and abscisic acid activity in tuberous roots. Journal of Plant Physiology, 118(4), 357366.
Mohamed, F.H., Awny, S.A. and Moursy, M.M. 1992. In vitro tuberization of potato. The combined effects of sucrose, kinetin and NAA. Proc. of the $5^{\text {th }}$ Egyptian-Italian Symp.on Biotechnology, Assuit University, Egypt.

Mohamed, F.H. and Shaaban, M.M. 1995. Monitoring Nutrient Levels during the in vitro Tuberization of Potato. HortScience, 30(4), 752 (Abstract).

Murashige, T. and Skoog, F. 1962. A revised medium for rapid growth and bio-assays with tobacco tissue cultures. Physiologia Plantarum, 15(3), 473-497.

Myeong C., Yiens, Park Y.E., Kim K.J., Cho H.M. and Hann H.B. 1990. Study on seed potato influences of several factors on in vitro tuberization of shoot nodes in potato c.v. Dejima. Res. Dep. Rural. Dev. Adm (Shweon). 3: 46-53.

Nowak, J., and Colborne, D. 1989. In vitro tuberization and tuber proteins as indicators of heat stress tolerance in potato. American Potato Journal, 66(1), 35-45.

Nikopoulos, D.P. 1993. In vitro potato microtuber production (Doctoral Dissertation, University of Bath (United Kingdom)), 338 pages.

Papathanasiou, F., Watson, S. and Harvey, B. M.R. 1994. Effect of explant stem length on potato (Solanum tuberosum L.) microtuber formation in vitro. In Physiology, Growth and Development of Plants in Culture (pp. 249253). Springer Netherlands.

Roumeliotis, E., Kloosterman, B., Oortwijn, M., Kohlen, W., Bouwmeester, H.J., Visser, R. G. and Bachem, C.W. 2012. The effects of auxin and strigolactones on tuber initiation and stolon architecture in potato. Journal of Experimental Botany, 63(12), 4539-4547.

Sharma, S., Venkatasalam, E.P., Patial, R., Latawa, J. and Singh, S. 2011. Influence of gelling agents and nodes on the growth of potato microplant. Potato Journal, 38(1), 41-46.

Struik, P. C. 1999. Influence of bud position on the formation of tubers on multiple node cuttings of potato (Solanum tuberosum L.). Potato Research, 42(1), 1-8.

Tábori, K., Ferenczy, A. and Dobránszki, J. (2000). Effects of culture density on growth and in vitro tuberization capacity of potato plantlets. Acta AgronomicaHungarica, 48(2), 185-189.

Wang, B. and Langille, A.R. 2007. Response of a gibberellin-deficient potato mutant to induction and growth regulators as a working model for tuber initiation. HortScience, 42(3), 540-543. 